medRxiv preprint doi: https://doi.org/10.1101/2022.01.25.22269867; this version posted February 3, 2022. The copyright holder for this preprint (which was not certified by peer review) is the author/funder, who has granted medRxiv a license to display the preprint in perpetuity.

It is made available under a CC-BY-NC-ND 4.0 International license .

\title{
Is mandatory vaccination in population over 60 adequate to control the COVID-19 pandemic in E.U.?
}

\author{
N.P. Rachaniotis, T.K. Dasaklis, F. Fotopoulos, M. Chouzouris, V. Sypsa, A. Lyberaki and \\ P. Tinios
}

Vaccine hesitancy, which potentially leads to refusal or delayed acceptance of COVID-19 vaccines, is considered a key driver for the increasing death toll from the pandemic in the E.U.. European Commission and several member states' governments are either planning or have already directly or indirectly announced mandatory vaccination for individuals aged over 60 , the group repeatedly proved to be the most vulnerable. In this paper, an assessment of this strategy benefits is attempted. This is done by examining the reduction of Standard Expected Years of Life Lost (SEYLL) per person of the EU population over 60 as a function of their vaccination percentage. Publicly available data and some first results of the second iteration of the SHARE COVID-19 survey conducted during the summer of 2021 on acceptance of COVID-19 vaccines are used as input.

Keywords: COVID-19; mandatory vaccination; SEYLL

\section{Introduction}

Two years after its emergence in Wuhan, China, the global spread of SARS-CoV-2, the pathogen that caused the pandemic COVID-19, continues to strain healthcare systems. By January $3^{\text {rd }}$, 2022, 290,157,607 confirmed cases of COVID-19, including 5,443,753 deaths, were reported globally (COVID-19 Map - Johns Hopkins Coronavirus Resource Center (jhu.edu)). Up to December 2020, due to the absence of effective therapies and vaccines, countries were limited to Non-Pharmaceutical Interventions (NPIs) to control the spread of the disease and minimize death rates. They included, inter alia, social distancing and lockdowns, travel restrictions, face masks, teleworking, etc. As vaccines became available, countries tried to develop exit strategies from the pandemic. These strategies aimed to balance the optimum utilization of vaccine resources which became gradually available) and the retention of some NPIs.

Over the same period, the European Union (E.U.) reported more than 57,000,000 confirmed cases and 906,000 deaths (COVID-19 Data Explorer - Our World in Data). The increasing death toll from the pandemic in E.U. was attributed to two major reasons: vaccine hesitancy, which lies behind refusal or delayed acceptance of vaccines, and the advent of the Delta variant in March 2021. The latter substantially increased the waning of vaccines' effectiveness, especially for ages over 60 - those who account for more than $90 \%$ of the total deaths from COVID-19 in Europe (Hoffmann and Wolf, 2021).

The consequence is an increasing discussion across the E.U. of ways to convince the unvaccinated. With the notable exception of health care personnel, who were obliged to get vaccinated in several E.U. countries until November 2021, the measures relied on negative incentives, in the form of COVID-19 "green passes" to limitations targeting only the unvaccinated population. However, an increasing number of countries have implemented or consider implementing mandatory vaccination (Table 1), while the European Commission has called for a horizontal E.U. discussion on the topic. Vaccination is defined as a legal obligation for subsections of the population, while direct penalties are envisaged in the form of fines or suspension of employment. However, even where the threat of mandatory vaccination exists, a significant fraction of the population remain unconvinced and appear to deny vaccination at all costs. 
medRxiv preprint doi: https://doi.org/10.1101/2022.01.25.22269867; this version posted February 3, 2022. The copyright holder for this preprint (which was not certified by peer review) is the author/funder, who has granted medRxiv a license to display the preprint in perpetuity.

It is made available under a CC-BY-NC-ND 4.0 International license .

\begin{tabular}{|c|c|}
\hline Country & Policy \\
\hline Austria & Compulsory vaccination for all adults from February $1^{\text {st }}, 2022$ \\
\hline France & $\begin{array}{c}\text { Compulsory vaccination for health care personnel, firefighters and } \\
\text { transportation workers }\end{array}$ \\
\hline Greece & $\begin{array}{r}\text { Compulsory vaccination for health care personnel, fines for unvaccinated } \\
\text { people over } 60 \text { from January } 15^{\text {th }}, 2022\end{array}$ \\
\hline Hungary & $\begin{array}{c}\text { Compulsory vaccination for health workers, state school teachers and in } \\
\text { public institutions }\end{array}$ \\
\hline Italy & $\begin{array}{c}\text { Compulsory vaccination for non-working people over 60, health care } \\
\text { personnel, teachers, military, police and rescue crews }\end{array}$ \\
\hline Latvia & Compulsory vaccination for health care personnel, teachers and care facilities \\
\hline
\end{tabular}

Table 1. E.U. countries compulsory vaccination policies by January 6, 2022.

How can we judge the potential efficacy of vaccine mandates? This question necessitates computing a counterfactual. This would rest on assuming how many more people will be vaccinated as a direct result of the mandate, who would not have been vaccinated otherwise. This assumption needs to be supplemented by a metric of the gains from vaccination. This paper chooses for this purpose the Standard Expected Years of Life Lost (SEYLL) per person of E.U. population over 60. SEYLL is a standard metric used in burden-of-disease estimations. It calculates life years lost compared with a standardised reference life table -which in the case examined is common across the EU. In other words, the gains of the mandates are identified as the averted SEYLL should the mandated obligation succeed - i.e. if the people who would not have been vaccinated on their own are pushed to be protected.

Publicly available data are used to compute the benchmark SEYLL, while findings from the second iteration of the SHARE COVID-19 survey conducted during the summer of 2021 are used to proxy the numbers of people in each country who resist voluntary vaccination.

The results showcase policy recommendations regarding the pandemic containment in E.U.. They could support decision-makers in suggesting a policy pathway to be followed until the majority of the population is vaccinated and argue in favor or against vaccine mandates at a country or E.U. level.

The remainder of this paper is organized as follows. Section 2 provides a review of the relevant literature. In Section 3, the proposed methodology of the study is described, whereas in Section 4 the results are presented. Finally, Section 5 discusses the study's results and their policy implications.

\section{Background literature}

Large differences in country-specific COVID-19 mortality rates have prompted debate and speculations about the reasons that lie behind it. Many factors have been examined recently, including genetic, viral, medical, socioeconomic and environmental ones. Nevertheless, reliable data proved from the very beginning that the crude Case Fatality Rate (CFR) of COVID-19 is predominantly determined by the proportion of population aged older than 60 years of all individuals diagnosed with SARS-CoV-2 infection (Hoffmann and Wolf, 2021). In consequence, the question that naturally arises is whether a targeted vaccination of the ages over 60 would be sufficient in order to mitigate the impact of the pandemic.

Trying to answer this question, a literature stream, even before the advent of vaccines, focused on the possible benefits of combining vaccination with NPIs with various levels of vaccines efficiency (Getz et al., 2020; Choi and Shim, 2020; Iboi et al., 2020; Maltsev and Stern, 2020). In order to eliminate disease transmission, a highly effective vaccine is required and complementing vaccination with NPIs will always yield optimal containment results (Kuzdeuov et al., 2020). Vaccination against COVID-19 initiated globally in December 2020. After a year of continuous testing, it is proven that vaccine effectiveness against symptomatic disease and hospitalization 
medRxiv preprint doi: https://doi.org/10.1101/2022.01.25.22269867; this version posted February 3, 2022. The copyright holder for this preprint (which was not certified by peer review) is the author/funder, who has granted medRxiv a license to display the preprint in perpetuity.

It is made available under a CC-BY-NC-ND 4.0 International license .

falls significantly after a time interval of $20-25$ weeks (5 to 6 months) from their vaccination completion against the dominating till December 2021 Delta variant. Waning is faster in older adults and those in a clinical risk group (Andrews et al., 2021; Han et al., 2021).

Vaccines aim to reduce premature deaths caused directly or indirectly by COVID-19. To capture vaccines efficiency in this paper, the metric used is SEYLL per living person aged over 60. SEYLL, a specific form of Years of Life Lost (YLL), is a standard metric used in burden-of-disease estimations. It calculates life years lost compared with a standardised reference life table. In other words a person's life expectancy at each age is estimated based on the lowest observed agespecific mortality rates across all countries in the EU. The major features of this choice are:

- It regards all deaths as important but those affecting younger individuals (but still over 60) as particularly important, given that for their case more life years are lost. This has the indirect impact of placing greater weight on lower income E.U. countries in which younger deaths are more common. Thus, understanding the mortality impact of COVID-19 requires not only counting the dead but also analyzing how premature those deaths are

- It values a death at a given age identically across all countries in the EU, regardless of differences in national life expectancy or income per capita. Otherwise a death occurring in a high longevity, richer country would count for more than one occurring in a poorer, less long lived country.

Given its egalitarian emphasis, this metric is selected in the proposed Fair Priority Model for allocation of vaccines, thus rendering it a suitable assessment tool (Emanuel et al., 2020; Herzog et al., 2021; Wouters et al., 2021).

YLL have been used to assess COVID-19 effects in some papers, either studying a single country (e.g. Quast et al., 2020; Rommel et al., 2021) or several countries together(e.g. Mitra et al., 2020; Oh et al., 2020; i Arolas et al., 2021; Vieira et al., 2021) - though before vaccination was available. Only Ferenci's (2021) research work took place in the first months of the vaccination campaign in Hungary.

This paper attempts to express SEYLL from COVID-19 per living person aged over 60 in E.U. as a function of population vaccination coverage. Developing such an aggregated model could be useful for policymakers to assess strategies that favor mandatory vaccination affecting this age group, both at a country or even at E.U. level, in terms of how much these strategies can reduce the total death toll should a particular vaccination level can be achieved.

\section{Methodology}

Available country-level age- and gender-specific data on COVID-19 deaths for the ages over 60 in the 27 E.U. countries from 25 $5^{\text {th }}$ May 2021 to 25th November 2021 from the COVerAGE database (Riffe et al., 2021), freely available from the Open Science Framework (Riffe et al., 2021), were used. The COVerAGE data was processed and stratified to three 10-year intervals, i.e. 60-69, 70-79 and 80+, separately for females and males, across countries. Countries' missing data were filled in from their national health authority websites and national press reports. Agestratified data to the same 10-year intervals on weekly numbers of vaccinations in E.U. countries up to the $25^{\text {th }}$ of November 2021 were collected from the European Centre for Disease Prevention and Control (ECDC). Germany and Netherlands that do not provide these data, so were filled in from national press reports and relevant research work filled in.

This specific six-months period (25/5/2021-25/11/2021) was selected for three reasons:

1. The majority of E.U countries were able to provide their citizens over 60 the opportunity to complete their vaccination until the end of May 2021

2. Vaccines effectiveness wanes significantly after 6 months from its completion, especially among the elderly.

3. On November $26^{\text {th }} 2021$ the WHO classified Omicron as a variant of global concern, which eventually prevailed over Delta variant at the end of December in most E.U. countries. The Omicron variant is still under examination regarding its CFR and vaccines 
medRxiv preprint doi: https://doi.org/10.1101/2022.01.25.22269867; this version posted February 3, 2022. The copyright holder for this preprint (which was not certified by peer review) is the author/funder, who has granted medRxiv a license to display the preprint in perpetuity. It is made available under a CC-BY-NC-ND 4.0 International license .

effectiveness against it. Therefore it is not possible yet to gauge the mandatory vaccination benefits for the $60+$ age group.

The E.U. population over 60 intending to be vaccinated was captured from the Survey of Health, Ageing and Retirement in Europe (SHARE) (www.share-project.org). The analysis used data from the second iteration of the SHARE COVID-19 Survey. This re-interviewed 46,989 respondents aged 50 years and older ( $91 \%$ of whom were 60 years and older) of the first SHARE COVID-19 Survey, and was fielded from June to August 2021 in all 28 countries participating in SHARE (26 EU countries plus Switzerland and Israel). SHARE's second COVID-19 survey remains one of the few, if not the only large-scale study, that covers all E.U. countries and has collected data on individuals' situation during the pandemic, using sampling methodologies that provide internationally comparable data.

All respondents were asked whether they had been vaccinated against COVID-19 at least once. "Information on their intention to do so was requested-inquiring whether they had already scheduled an appointment for vaccination, wanted to get vaccinated, were still undecided or did not want to get vaccinated at all" (Bergmann et al., 2021). It is this last percentage - i.e. those adamant they would not be vaccinated - that we use to proxy the upper vaccination limit in case of fully enforcing mandatory vaccination for the ages over 60 for every E.U. country in SHARE. Given that the mandatory vaccination strategy is considered predominately in the EU, the two non-EU countries, Switzerland and Israel, were excluded from the analysis.

The total expected years of life lost due to COVID-19 for the over-60 population, denoted SEYLLt, is

where:

$$
S E Y L L_{t}=\sum_{a} e_{a} D_{a}
$$

$\mathrm{D}_{\mathrm{a}}$ : denotes deaths in the six-month period due to COVID-19 in a 10-years interval a, a="60-69", "70-79", "80+".

$\mathrm{e}_{\mathrm{a}}$ : is a measure of the expected years of life that remain to be lived for a death from any cause at age a. These coefficients are specified by MLTW tables, separately for females and for males, thus forming the "standard" in the SEYLL metric.

In order to relate SEYLL to the population structure of E.U. countries and to capture their significanty different mortality rates, the years lost per death SEYLL $d$ and the years lost per living person SEYLL $p$ are considered (Marshall, 2009):

$$
\begin{aligned}
& S E Y L L_{d}=\frac{\sum_{a} e_{a} D_{a}}{\sum_{a} D_{a}} \\
& \text { SEYLL } L_{p}=\frac{\sum_{a} e_{a} D_{a}}{P}
\end{aligned}
$$

where $\mathrm{P}$ : is the population size for people over 60 . E.U. countries' population structure projection for 2021 by age and gender (www.ec.europa.eu/eurostat) is used.

\section{Results}

Table 2 illustrates the actual vaccination percentages by $25 / 11$, all of which predated mandatory vaccinations, and are hence fully voluntary. The table shows SEYLL ${ }_{d}$ in years and SEYLL in days from $25 / 5$ to $25 / 11$ for the $60+$ age group in the $27 \mathrm{E} . U$ countries. The calculated SEYLL values (mean $=11.3$ years, s.d. $=0.74$ years) - shown in Figure 1 - are consistent with the results of several 
medRxiv preprint doi: https://doi.org/10.1101/2022.01.25.22269867; this version posted February 3, 2022. The copyright holder for this preprint (which was not certified by peer review) is the author/funder, who has granted medRxiv a license to display the preprint in perpetuity.

It is made available under a CC-BY-NC-ND 4.0 International license .

relevant studies, where SEYLL $d$ were estimated between 10 and 13 years in developed countries (Hanlon et al., 2020). The metric is useful for comparison purposes to other causes of death within E.U. countries, e.g. in most of them COVID19 is the third cause of death after cancer and cardiovascular diseases (Vieira et al, 2021). However, it is not capturing the significantly different mortality rates (deaths per million people) between countries. This is obtained with the calculation of SEYLLp.

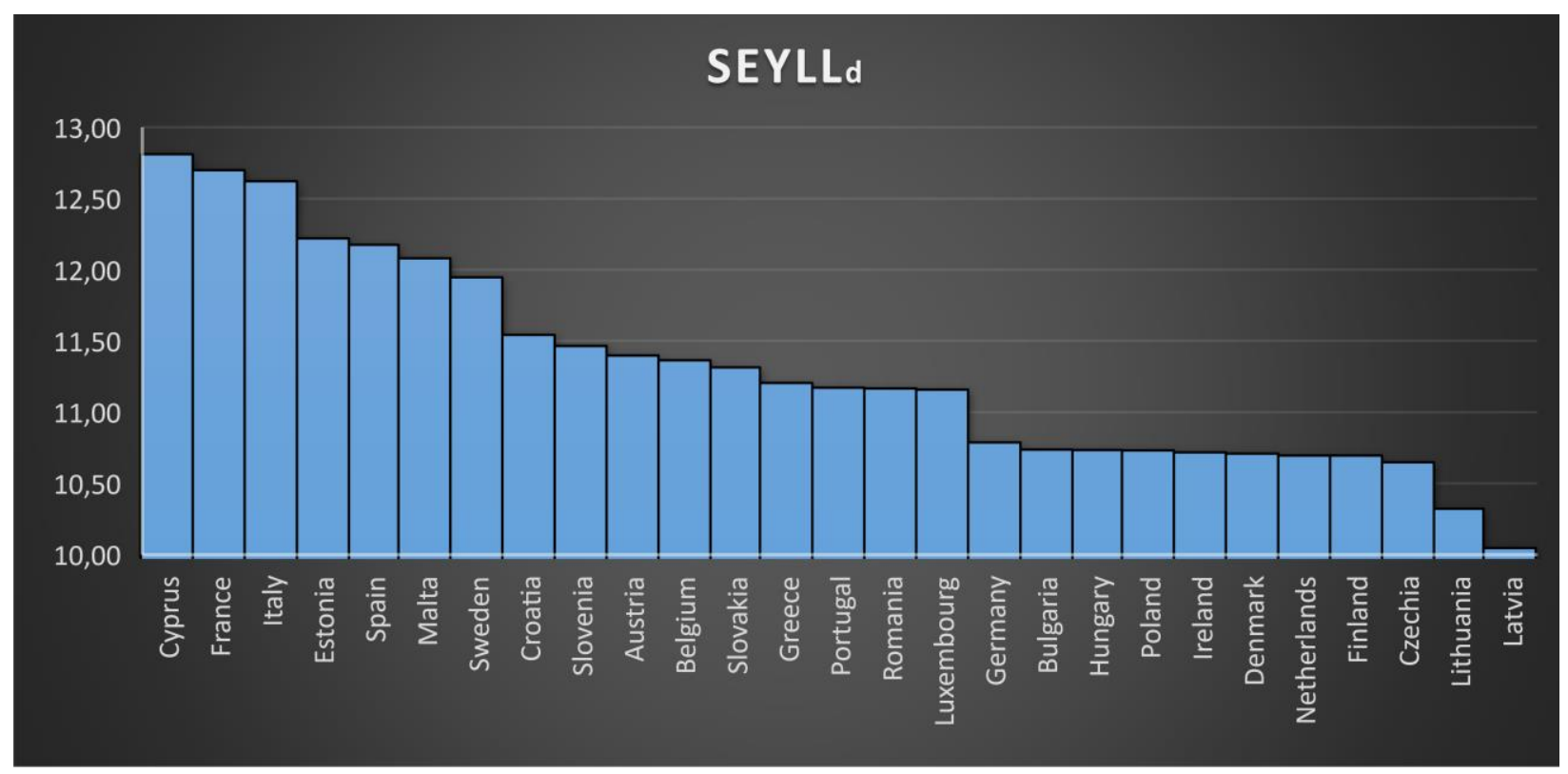

Figure 1. SEYLL $L_{d}$ for the 27 E.U. countries.

The days of life lost per living person aged over 60 for the examined 6-months period (mean=2.64 days, s.d. $=2.42$ days, $\min =0.44$ days, $\max =9.19$ ) form a representative metric of the significant pandemic's negative effects on every E.U. country. They measure how many fewer days a representative individual over 60 expecto to live, as a direct result of COVID-19 morbidity occurring in these six months.

In order to relate SEYLL for the population over 60 to their vaccination percentage coverage, an approximated value function was calculated from the data of Table 1 using the least squares method. The best approximation function calculated was (Figure 2):

$$
S E Y L L_{p}=13.423-0.1309 \times \text { Vaccination percentage }
$$

with $\mathrm{R}^{2}=79.62 \%$. The $95 \% \mathrm{Cl}$ for the intercept is $[11.13,15.71]($ s.e. $=1.11)$ and for the slope is [$0.16,-0.10]($ s.e. $=0.01)$. 
medRxiv preprint doi: https://doi.org/10.1101/2022.01.25.22269867; this version posted February 3, 2022. The copyright holder for this preprint (which was not certified by peer review) is the author/funder, who has granted medRxiv a license to display the preprint in perpetuity.

It is made available under a CC-BY-NC-ND 4.0 International license .

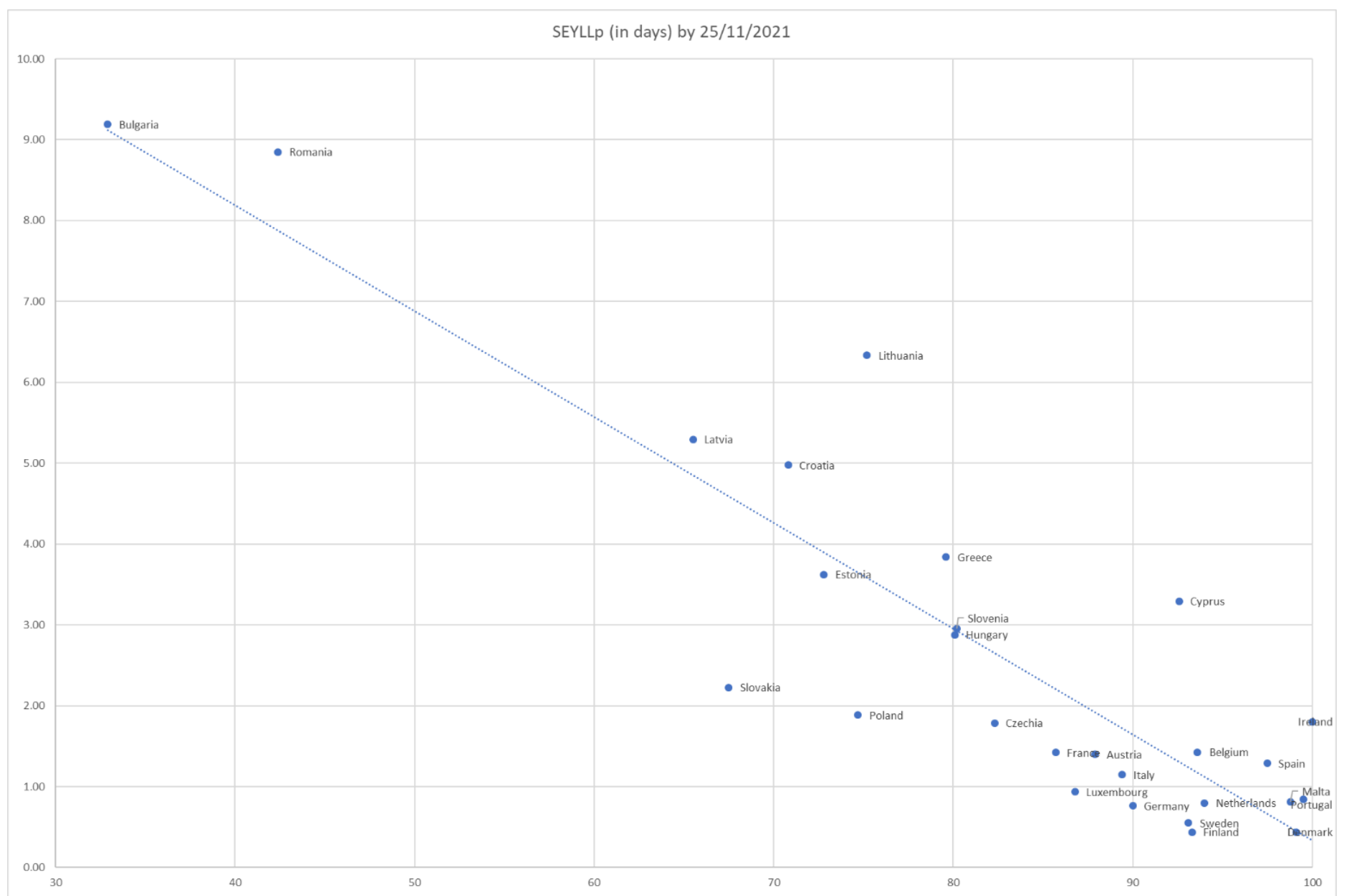

Figure 2. SEYLL (in days) for the population over 60 in the 27 E.U. countries from $25 / 5 / 2021$ to $25 / 11 / 2021$ vs. their percentage vaccination coverage.

SHARE's second iteration COVID-19 Survey vaccination intention percentages correspond well with E.U. country-level vaccination rates reported by the European Centre for Disease Prevention and Control for the 60+ populations by 25 November 2021 (ECDC vaccinetracker, 2021). The percentage of those over 60 who say they did not want to get vaccinated is used to approximate the upper vaccination limit in case of enforcing mandatory vaccination for these ages in every E.U. country. The actual vaccination percentages were used for the only two countries where vaccination percentage slightly exceeded this limit by 25 November 2021, namely Denmark and

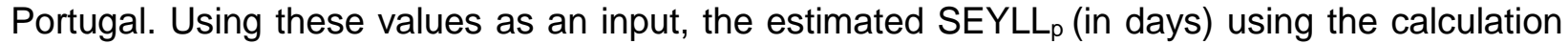
approximation function is illustrated in Table 3 . Figure 3 highlights the differences between the 27 E.U. countries' SEYLL for the $60+$ population by $25 / 11 / 2021$ and their estimated respective values in the case of mandatory vaccination. In other words, Figure 3 shows the potential gains in fewer lives lost should mandates succeed to lead every recalcitrant individual to vaccination. 


\begin{tabular}{|c|c|c|c|c|c|}
\hline Country & $\begin{array}{l}\text { Voluntary } \\
\text { Vaccination } \\
\text { percentage by } \\
25 / 11 \text { in the } 60+ \\
\text { age group }\end{array}$ & $\begin{array}{l}\text { SEYLL } \\
\quad \text { (in } \\
\text { years) }\end{array}$ & $\begin{array}{l}\text { SEYLL } \text { (in } \\
\text { days) for the } \\
60+\text { age group } \\
\text { from } 25 / 5 \text { to } \\
25 / 11\end{array}$ & $\begin{array}{c}\text { Upper } \\
\text { vaccination } \\
\text { limit from } \\
\text { SHARE } \\
\text { COVID-19 } \\
\text { survey }(\%) \text { for } \\
\text { ages } 60+\end{array}$ & $\begin{array}{l}\text { SEYLL } \\
\text { estimation } \\
\text { (days) }\end{array}$ \\
\hline Austria & 87.9 & 11.40 & 1.40 & 90.51 & 1.58 \\
\hline Belgium & 93.6 & 11.37 & 1.43 & 97.65 & 0.64 \\
\hline Bulgaria & 32.9 & 10.74 & 9.19 & 63.30 & 5.14 \\
\hline Croatia & 70.8 & 11.54 & 4.98 & 90.43 & 1.59 \\
\hline Cyprus & 92.6 & 12.81 & 3.29 & 93.60 & 1.17 \\
\hline Czechia & 82.3 & 10.65 & 1.79 & 93.11 & 1.24 \\
\hline Denmark & 99.1 & 10.71 & 0.44 & $99.10^{*}$ & 0.45 \\
\hline Estonia & 72.8 & 12.22 & 3.62 & 90.07 & 1.63 \\
\hline Finland & 93.3 & 10.70 & 0.44 & 97.84 & 0.62 \\
\hline France & 85.7 & 12.70 & 1.42 & 94.62 & 1.04 \\
\hline Germany & 90 & 10.79 & 0.76 & 95.29 & 0.95 \\
\hline Greece & 79.6 & 11.21 & 3.84 & 92.38 & 1.33 \\
\hline Hungary & 80.1 & 10.73 & 2.88 & 92.67 & 1.29 \\
\hline Ireland & 100 & 11.86 & 1.80 & 100.00 & 0.33 \\
\hline Italy & 89.4 & 10.72 & 1.15 & 96.93 & 0.74 \\
\hline Latvia & 65.5 & 12.62 & 5.30 & 77.69 & 3.25 \\
\hline Lithuania & 75.2 & 10.05 & 6.34 & 84.00 & 2.43 \\
\hline Luxembourg & 86.8 & 10.32 & 0.93 & 94.96 & 0.99 \\
\hline Malta & 98.8 & 11.16 & 0.81 & 98.80 & 0.49 \\
\hline Netherlands & 94 & 12.08 & 0.80 & 97.43 & 0.67 \\
\hline Poland & 74.7 & 10.70 & 1.88 & 89.67 & 1.68 \\
\hline Portugal & 99.5 & 11.80 & 0.84 & 99.50* & 0.40 \\
\hline Romania & 42.4 & 10.73 & 8.85 & 63.81 & 5.07 \\
\hline Slovakia & 67.5 & 11.17 & 2.23 & 86.02 & 2.16 \\
\hline Slovenia & 80.2 & 11.17 & 2.95 & 88.97 & 1.78 \\
\hline Spain & 97.5 & 11.32 & 1.29 & 97.82 & 0.62 \\
\hline Sweden & 93.1 & 11.47 & 0.55 & 99.17 & 0.44 \\
\hline
\end{tabular}

${ }^{*}$ Actual vaccination percentages by $25 / 11 / 2021$

Table 2. Vaccination percentages by 25/11, SEYLL ${ }_{d}$ in years, SEYLL $L_{p}$ in days from $25 / 5$ to $25 / 11$ for the $60+$ age group, upper vaccination limits for $60+$ age group and estimated SEYLL for the 27 E.U. countries. 
medRxiv preprint doi: https://doi.org/10.1101/2022.01.25.22269867; this version posted February 3, 2022. The copyright holder for this preprint (which was not certified by peer review) is the author/funder, who has granted medRxiv a license to display the preprint in perpetuity.

It is made available under a CC-BY-NC-ND 4.0 International license .

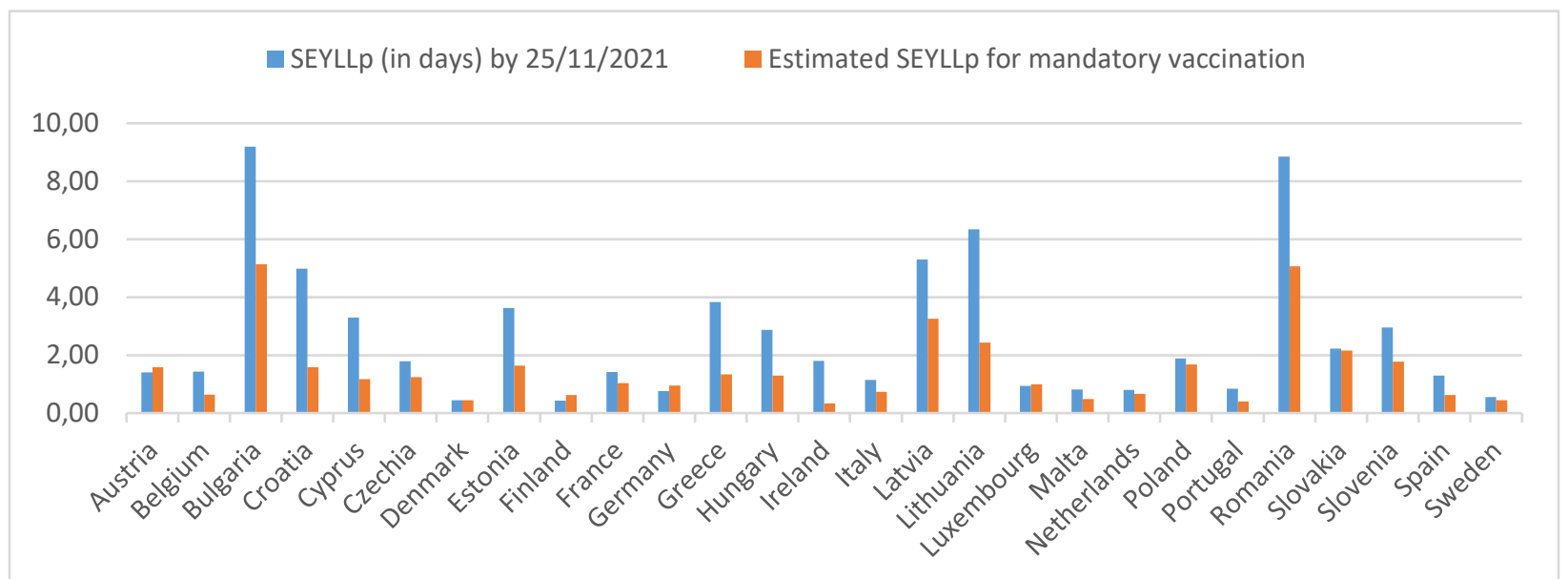

Figure 3. Differences between the 27 E.U. countries' SEYLL for the 60+ population by 25/11/2021 and their estimated respective values in the case of a mandatory vaccination.

\section{Discussion}

The simple calculations of this paper indicate that vaccination emerges to be the most important factor in explaining variations in in E.U. countries' mortality from COVID-19 for age groups over 60. This result emerges naturally, without needing to employ complex mathematical models nor to bring other variables to bear. Its impact is significant, not only in terms of the number of deaths but also in terms of years of life lost that could be averted if the vaccination coverage in this age group increases.

More specifically, the values of yielded $\mathrm{R}^{2}$ and $\mathrm{R}^{2}$ adj, $79.62 \%$ and $78.8 \%$ respectively, and indicate that almost $80 \%$ of the variability COVID-19 mortality rates for the ages over 60 in E.U. countries can be explained solely from their vaccination coverage. In addition, the E.U.-wide approximate value function for SEYLL ${ }_{p}$ yields a Mean Absolute Deviation (MAD) of 0.82 days for the vaccination coverage on $25 / 11 / 2021$, implying an impressive fit for such a parsimonious model. The number of deaths occurring at ages above 60 justifies policy responses to protect these vulnerable population groups. Whereas vaccine mandates exist and are common in all E.U. countries for children and childhood diseases, fully one year after the vaccination kick-off against COVID-19, there appears to be a reticence to proceed with equivalent mandates for COVID to affect the adult population. The need for such a mandate - in the sense of the share of the vulnerable groups who are not vaccinated voluntarily differs widely in the EU.

However, from Figure 3 it is obvious that in, say Bulgaria, Croatia, Cyprus, Estonia, Greece, Hungary, Latvia, Lithuania and Romania, even if the predicted upper vaccination limit is achieved and therefore mandates are $100 \%$ succesful, SEYLL $L_{p}$ would still remain high, as death rates are high. Thus, in order to bring the impact of the pandemic under control, the adaptation of some NPIs will still be necessary, which is aligned with the corresponding literature stream. Especially for Bulgaria and Romania, even when the lower bounds of the $95 \% \mathrm{Cl}$ are used for the estimation, there will still be a need for additional NPIs to minimize SEYLL , as it will be greater than one day per semester.

The study has several limitations. As countries are at different stages of the pandemic trajectory, it is a snapshot of the impacts of COVID-19 on SEYLL $p$ by November 25, 2021. The Delta variant impacts in the examined time span of six months are probably mostly captured, but the advent of the Omicron variant at the end of November 2021 and its effects are not. The Omicron variant spreads more easily than the Delta and it is expected that anyone with Omicron infection can spread the virus to others, even if they are vaccinated or asymptomatic. Current vaccines are expected to protect against severe illness, hospitalizations, and deaths due to infection with the 
medRxiv preprint doi: https://doi.org/10.1101/2022.01.25.22269867; this version posted February 3, 2022. The copyright holder for this preprint (which was not certified by peer review) is the author/funder, who has granted medRxiv a license to display the preprint in perpetuity. It is made available under a CC-BY-NC-ND 4.0 International license .

Omicron variant, but breakthrough infections in elderly people who are fully vaccinated are likely to occur, with an impact that necessitates more time to estimate.

Futhermore, SEYLL figures may be misestimated. On one hand, COVID-19 deaths may not be accurately recorded in some countries; most of the evidence suggests that there is a net underestimation of the total death toll on the aggregate level. On the other hand, those dying from COVID-19 may be an at-risk population whose remaining life expectancy is shorter than the average person's due to co-morbidities (Devleesschauwer et al., 2020). Consequently, SEYLL due to COVID-19 may be overestimated.

Nevertheless, the study confirmed the large mortality impact of COVID-19 among the elderly, even using a metric that places greater weight on deaths occurring at younger ages. It also calls for devising policies that protect vulnerable demographics losing the largest number of life-years. Finally, in order to evaluate the effectiveness of mandatory vaccination against COVID-19 for ages over 60, country-specific data must be studied carefully, focusing on the vaccination adherence divergence in the E.U..

\section{References}

Andrews, N., Tessier, E., Stowe, J., Gower, C., Kirsebom, F., Simmons, R., ... \& Bernal, J. L. (2021). Vaccine effectiveness and duration of protection of Comirnaty, Vaxzevria and Spikevax against mild and severe COVID-19 in the UK. MedRxiv.

Bergmann, M., Hannemann, T. V., Bethmann, A., \& Schumacher, A. (2021). Determinants of SARS-CoV-2 Vaccinations in the $50+$ Population.

Chapman, L. A., Barnard, R. C., Russell, T. W., Abbott, S., Van Zandvoort, K., Davies, N. G., \& Kucharski, A. J. (2021). Unexposed populations and potential COVID-19 burden in European countries. medRxiv.

Choi, W.; Shim, E. Optimal strategies for vaccination and social distancing in a game-theoretic epidemiologic model. J. Theor. Biol. 2020, 505, 110422.

Devleesschauwer, B., McDonald, S. A., Speybroeck, N., \& Wyper, G. M. (2020). Valuing the years of life lost due to COVID-19: the differences and pitfalls. International Journal of Public Health, 65(6), 719-720.

Emanuel, E. J., Persad, G., Kern, A., Buchanan, A., Fabre, C., Halliday, D., ... \& Richardson, H. S. (2020). An ethical framework for global vaccine allocation. Science, 369(6509), 1309-1312.

Ferenci, T. (2021). Different approaches to quantify years of life lost from COVID-19. European Journal of Epidemiology, 1-9.

Getz, W.M.; Luisa-Vissat, L.; Salter, R. A Contact-Explicit Covid-19 Epidemic and Response Assessment Model. medRxiv 2020, doi:10.1101/2020.07.16.20155812.

Han, S., Cai, J., Yang, J., Zhang, J., Wu, Q., Zheng, W., ... \& Yu, H. (2021). Time-varying optimization of COVID-19 vaccine prioritization in the context of limited vaccination capacity. Nature communications, 12(1), 1-10.

Hanlon, P., Chadwick, F., Shah, A., Wood, R., Minton, J., McCartney, G., ... \& McAllister, D. A. (2020). COVID-19-exploring the implications of long-term condition type and extent of multimorbidity on years of life lost: a modelling study. Wellcome Open Research, 5.

Herzog, L. M., Norheim, O. F., Emanuel, E. J., \& McCoy, M. S. (2021). Covax must go beyond proportional allocation of covid vaccines to ensure fair and equitable access. bmj, 372.

Hoffmann, C., \& Wolf, E. (2021). Older age groups and country-specific case fatality rates of COVID-19 in Europe, USA and Canada. Infection, 49(1), 111-116.

i Arolas, H. P., Acosta, E., López-Casasnovas, G., Lo, A., Nicodemo, C., Riffe, T., \& Myrskylä, M. (2021). Years of life lost to COVID-19 in 81 countries. Scientific reports, 11(1), 1-6.

Iboi, E.A.; Ngonghala, C.N.; Gumel, A.B. Will an imperfect vaccine curtail the COVID-19 pandemic in the U.S.? Infect. Dis. Model. 2020, 5, 510-524. 
medRxiv preprint doi: https://doi.org/10.1101/2022.01.25.22269867; this version posted February 3, 2022. The copyright holder for this preprint (which was not certified by peer review) is the author/funder, who has granted medRxiv a license to display the preprint in perpetuity. It is made available under a CC-BY-NC-ND 4.0 International license .

Kuzdeuov, A.; Baimukashev, D.; Karabay, A.; Ibragimov, B.; Mirzakhmetov, A.; Nurpeiissov, M.; Lewis, M.; Varol, H.A. A network-based stochastic epidemic simulator: Controlling covid-19 with region-specific policies. IEEE J. Biomed. Health Inform. 2020, 24, 2743-2754.

Maltsev, A.V.; Stern, M.D. Social heterogeneity drives complex patterns of the COVID-19 pandemic: Insights from a novel Stochastic Heterogeneous Epidemic Model (SHEM). medRxiv 2020, doi:10.3389/fphy.2020.609224.

Marshall, R. (2009). Standard Expected Years Of Life Lost (SEYLL) As A Measure Of Disease Burden: An Investigation Of Its Presentation, Meaning And Interpretation. Handbook of disease burdens and quality of life measures. New York, New York, NY: Springer; 2010. p. 401-13.

Mitra, A. K., Payton, M., Kabir, N., Whitehead, A., Ragland, K. N., \& Brown, A. (2020). Potential years of life lost due to COVID-19 in the United States, Italy, and Germany: an old formula with newer ideas. International journal of environmental research and public health, 17(12), 4392.

Oh, I. H., Ock, M., Jang, S. Y., Go, D. S., Kim, Y. E., Jung, Y. S., ... \& Yoon, S. J. (2020). Years of life lost attributable to COVID-19 in high-incidence countries. Journal of Korean medical science, 35(32).

Quast, T., Andel, R., Gregory, S., \& Storch, E. A. (2020). Years of life lost associated with COVID19 deaths in the United States. Journal of Public Health, 42(4), 717-722.

Rachaniotis, N.P.; Dasaklis, T.K.; Fotopoulos, F.; Tinios, P. A Two-Phase Stochastic Dynamic Model for COVID-19 Mid-Term Policy Recommendations in Greece: A Pathway towards Mass Vaccination. Int. J. Environ. Res. Public Health 2021, 18, 2497. https://doi.org/10.3390/ijerph18052497

Riffe T, Acosta E, Schöley J, Donzowa J, Kniffka MS. COVerAGE-DB: A database of COVID-19 cases and deaths by age. 2020 Apr 9 [cited 2021 Oct 21]; Available from: https://osf.io/mpwjq/ Riffe T, Acosta E, the COVerAGE-DB team, Acosta EJ, Manuel Aburto D, Alburez-Gutierrez A, et al. Data Resource Profile: COVerAGE-DB: a global demographic database of COVID-19 cases and deaths. Int J Epidemiol. 2021 May 15;50(2):390-390f.

Rommel, A., von der Lippe, E., Plass, D., Ziese, T., Diercke, M., an der Heiden, M., ... \& Wengler, A. (2021). The COVID-19 Disease Burden in Germany in 2020: Years of Life Lost to Death and Disease over the Course of the Pandemic. Deutsches Ärzteblatt International, 118(9), 145.

Vieira, A., Ricoca, V. P., Aguiar, P., Sousa, P., Nunes, C., \& Abrantes, A. (2021). Years of life lost by COVID-19 in Portugal and comparison with other European countries in 2020. BMC public health, 21(1), 1-8.

Wouters, O. J., Shadlen, K. C., Salcher-Konrad, M., Pollard, A. J., Larson, H. J., Teerawattananon, Y., \& Jit, M. (2021). Challenges in ensuring global access to COVID-19 vaccines: production, affordability, allocation, and deployment. The Lancet. 